\title{
Effect of Tax Revenue Mobilization on Income Inequalities in West African Economic and Monetary Union Countries (WAEMU)
}

\author{
Aichatou Mourfou ${ }^{1, *}$, Idrissa Mohamed Ouedraogo ${ }^{2}$ \\ ${ }^{1}$ Department of Economics and Management, University Thomas Sankara, Ouagadougou, Burkina-Faso \\ ${ }^{2} \mathrm{PhD}$ School, University Aube Nouvelle, Ouagadougou, Burkina-Faso
}

Email address:

aichatoumourfou@yahoo.fr (A. Mourfou)

*Corresponding author

\section{To cite this article:}

Aichatou Mourfou, Idrissa Mohamed Ouedraogo. Effect of Tax Revenue Mobilization on Income Inequalities in West African Economic and Monetary Union Countries (WAEMU). American Journal of Theoretical and Applied Business. Vol. 7, No. 1, 2021, pp. 8-15. doi: 10.11648/j.ajtab.20210701.12

Received: January 18, 2021; Accepted: January 27, 2021; Published: February 2, 2021

\begin{abstract}
This research examines the effect of different types of tax revenues on income inequality in WAEMU countries over the period 1996 to 2015. Double least squares (2SLS) are used as an estimation technique to analyze the effect of these different types of tax revenues, including total tax revenues (the sum of all revenues), direct tax revenues (which include profit and income taxes), domestic indirect tax revenues (e.g., value added tax and excise duties) and commercial tax revenues (e.g., customs duties). The results show that an increase in direct tax revenues leads to a reduction in income inequality. In other words, progressive income taxation allows for an efficient redistribution of income from richer to poorer people, which contributes strongly to the reduction of income inequality. On the other hand, indirect domestic tax revenues and commercial tax revenues are found to be neutral in income distribution. In fact, WAEMU countries, in order to compensate for the fiscal losses resulting from the reduction of customs tariffs, have adopted a reform of domestic taxation focused mainly on the development of non-progressive indirect taxes, i.e., taxes governed by liberal principles of fiscal neutrality: taxation must not disrupt individual choices of resource allocation. These tax reforms thus explain the neutrality of the effects of indirect taxation in the WAEMU zone. In the light of these results, the paper suggests that WAEMU countries should strengthen the progressivity of direct taxes and always maintain the neutrality of indirect taxes.
\end{abstract}

Keywords: Total Fiscal Pressure, Direct Fiscal Pressure, Domestic Indirect Fiscal Pressure, Commercial Fiscal Pressure, Income Inequality, 2SLS, WAEMU

\section{Introduction}

The tax structure of WAEMU countries is dominated by trade (commercial) tax revenues. In fact, as an annual average over the period 1996-2015, the rate of direct, indirect domestic and commercial tax pressure in the Union is, respectively, $3.34 \%, 4.08 \%$ and $4.83 \%$ of the Gross Domestic Product (GDP). This means that, in the WAEMU zone, indirect tax revenue is dominant.

According to the theory of optimal taxation, the increased mobilization of certain types of tax revenue can lead to distortions in the functioning of the economy [30, 38]. In other words, direct taxation reduces income inequality, whereas indirect taxation worsens income distribution.

The objective of this paper is to analyze the effect of different types of tax revenue (total tax pressure, direct tax pressure, indirect domestic tax pressure and commercial tax pressure) on income inequality in WAEMU countries from 1996-2015. Based on the economic literature, it is assumed that direct tax revenues reduce income inequality, while indirect taxation worsens the distribution of income in the economy [30, 38]. To test this assumption, double least squares (2SLS) are used as an estimation technique.

The plan for the rest of this article is as follows. First, we present the literature review, then the methodology, then the results followed by the interpretations, and finally the 
conclusion and policy implications.

\section{Literature}

Optimal taxation theory accounts for the redistributive effects of tax revenue mobilization [6, 17, 23, 29]. This theory states that the redistributive effect of a country's tax policy is a function of the progressivity of its tax system. According to this theory, direct taxes are progressive and therefore advocated to reduce income and wealth inequality, unlike indirect taxes which are regressive.

According to Bobe, generally speaking, theoretical work is concerned with distinguishing the impact of a direct tax (personal income tax, corporation tax, capital tax, property tax, transfer tax, inheritance tax, registration tax, capital gains tax, housing tax, refuse disposal tax, etc.) on the income of a person.) directly affecting the taxpayer's income from that of an indirect tax (turnover tax, VAT, customs duties, excise duties, tax on tobacco, alcohol and petrol, entertainment tax, etc.) levied on products, economic acts and paid by companies but paid by the clients of these companies [9].

Some authors assume that tax systems dominated by indirect taxes are regressive and therefore unequal $[6,15,16$, 30]. In fact, these taxes are used mainly from an efficiency perspective. These taxes may increase in proportion to the value taxed by applying a uniform rate regardless of the declared value. Proportional tax at a uniform and single rate on all income also exists. This is what Anglo-Saxons call the Flat Tax. As different income groups tend to consume similar goods (albeit in different proportions), it is generally difficult to achieve significant redistribution through indirect taxes. In addition, some goods are more important for the poor. For example, taxes on intermediate goods, such as fuel, are often considered regressive because they affect transport costs (thus increasing the price of goods consumed by the poor). Also, export taxes are regressive and generally affect small agricultural producers (who, while not poor, have relatively low incomes). The removal of these taxes, combined with the reduction of other implicit taxes on agriculture, should have a favourable impact on distribution and the poor.

Furthermore, Mirrlees warns that the progressivity of income tax can be questioned, as it varies according to the analysis methodology used [30]. Indeed, personal and corporate taxes are found to be regressive on the basis of a partial equilibrium analysis [42], but progressive on the basis of a general equilibrium analysis [33]. Then, for Mirrlees, it is necessary to provide for additional taxes on top of income tax such as negative income taxes. Specifically, he suggests introducing a tax scale that depends on working time and labor income [30].

Empirically, the majority of the work confirms the theory but sometimes with divergences. Younger shows that the tax system in Ghana is regressive from 1977 to 1978 and 1981 to 1982, but less regressive in 1987 and proportional in 1990 [46]. For Côte d'Ivoire, in 1985, taxes on fuel, export and import excise duties are regressive while other taxes are progressive [39]. Younger et al. find similar results in
Madagascar using data from the 1994 Permanent Household Survey [47].

In France, where households are identical with respect to all characteristics other than income and family size, an average tax rate that increases with primary income ensures that disposable income is less unequally distributed than income before taxation [31]. Chu, Davoodi, and Gupta, based on the literature and their estimates over the period 19701990, find that direct taxes and the ratio between direct and indirect taxes have a positive effect on income equality [11]. They also point out that there is a less unequal distribution of pre-tax income in developing countries than in OECD countries. Moreover, they indicate that developing countries have not been able to effectively implement taxation policies to reduce income inequality, unlike industrialized countries. Gautier confirms the latter result. He uses the concept of optimal taxation as a basis for analyzing the main tax policies that are currently being pursued in developing countries (lowering of tariffs, introduction and extension of VAT). He considers that it is mainly the criterion of efficiency, rather than that of fairness, that has prevailed in the implementation of reforms [19]. Thus, for this author, tax policies in developing countries are regressive.

Piketty and Saez analyze the evolution of income inequality in the United States of America (USA) in the 20th century [37]. To do so, they observe the secular evolution of the income shares of the top decile (the richest $10 \%$ of the population) in the USA. They arrive at a surprising result. Contrary to the theory of Kuznets, this evolution draws a Ushaped curve with a decrease in inequality during the first half of the 20th century followed by an increase in inequality from the 1970s onwards. Following their investigations, they find that progressive income tax played a decisive role in the evolution of income inequality in the USA during the 20th century. In fact, for these authors, the progressive taxation of income and wealth in the USA during the 20th century has led to a considerable reduction in income inequality.

In the same vein, Gemmell and Morrissey, on a set of six (06) African countries from 1960 to 1990 , find that personal income taxes are progressive, corporate taxes have a Ushaped effect (regressive then progressive), property taxes, indirect taxes and export taxes are regressive [20]. They find that, overall, tax systems are regressive when incomes are low. Similarly, Bird and Zolt find that the progressive effect of income taxes is very weak in developing countries [7]. The work of Peter, Buttrick, and Duncan on a panel of 189 countries from 1981 to 2005 corroborates these results: in high-income countries, there is a strong positive relationship between tax rates and income tax collection, in contrast to developing countries (low-income countries) where this relationship is very weak [35]. Also, comparing the tax systems of Latin America and Western Europe, Goni, Lopez, and Serven mention that the redistributive effect of the tax system is very high in Europe and very low in Latin America [21]. Kim and Kim, analyzing the evolution of income inequality in Korea over the period 1933-2010, find that progressive income taxation played a key role [24]. Piketty, 
in his latest essay "Capital in the 21st Century", using historical and comparative data from three centuries and more than twenty countries, finds that the dynamics of inequality in developed countries are explained by existing tax policies [36].

In sum, the empirical literature validates the theory but with country specificities. Unfortunately, few studies are made on the case of African countries, particularly those of the WAEMU. The econometric evaluation of the present research attempts to make up for this shortcoming.

\section{Methodology}

The aim is to present models, variables and estimation techniques.

\subsection{Theoretical and Empirical Models}

The Kuznets hypothesis is the main theoretical approach to assess the determinants of income inequality [26, 27]. Indeed, according to this author, income inequality follows an inverted " $U$ " curve, increasing initially with industrialization and then declining as workers move into the high productivity sectors of the economy. For him, the reduction of income inequality should not be the subject of any economic policy because inequality is the consequence of a "natural" economic process.

More recent models with a Kuznets curve are spreading beyond the movement of people and resources from agriculture to industry [5].

Based on these different theoretical approaches, works [11, $32,34]$ establish the theoretical model for the analysis of redistributive panel effects as follows:

$$
G_{i t}=f\left(X_{i t}, F_{i t}\right)
$$

Where $G_{i t}$ is the Gini inequality index of household disposable income for country $\mathrm{i}$ in year $\mathrm{t}, X_{i t}$ is a vector of control variables, $F_{i t}$ the different measures of tax revenue.

Adapting equation (1) in our context, the empirical model for this research is:

$$
\begin{gathered}
G_{i t}=\alpha_{0}+\alpha_{1} p i b h_{i t}+\alpha_{2} e d u c_{i t}+\alpha_{3} i n f_{i t}+\alpha_{4} w g i_{i t}+ \\
\alpha_{5} \operatorname{tax}_{i t}+\varepsilon_{i t}
\end{gathered}
$$

with $G_{i t}$ the Gini inequality index of household disposable income for country $\mathrm{i}$ in year $\mathrm{t}$; pibh, the logarithm of GDP per capita; educ, the gross enrolment ratio; inf, the inflation rate; $w g i$, the composite index of institutional quality; tax, a measure of pressure (overall tax pressure rate, direct tax pressure rate, domestic indirect tax pressure rate, and trade tax pressure rate). $\alpha_{0}$, the constant; $\alpha_{1}, \alpha_{2}, \alpha_{3}, \alpha_{4}$, and $\alpha_{5}$, the respective coefficients of the different explanatory variables in the equation; $\varepsilon_{i t}$, the error terms.

\subsection{Variables and Data Sources}

The endogenous variable is the Gini inequality index of household disposable income. The index ranges from 0 to 1 , where 0 represents perfect equality and 1 represents perfect inequality.

The variables of interest are tax revenue variables. First, there is the overall tax burden rate, which is equal to the ratio of total tax revenue (sum of direct, indirect domestic, commercial and other taxes) to GDP, and second, the direct tax burden rate, which is equal to the ratio of direct tax revenue (taxes on profits and personal income) to GDP. Then there is the rate of domestic indirect tax burden which is equal to the ratio of domestic indirect tax revenue (VAT and excise duties) to GDP, and finally the rate of commercial tax burden which is the ratio of commercial tax revenue (such as customs duties) to GDP. According to the theory, a positive sign is expected for the variables rate of domestic and commercial indirect tax burden, while a negative sign is expected for the variable direct tax burden.

The control variables are as follows:

The level of development approximated by GDP per capita: Kuznets states that an increase in the rate of economic growth in developing countries is accompanied by an increase in income inequality and yet reduces income inequality in developed countries [26]. WAEMU countries are developing countries, so a positive sign is expected.

The level of education is captured by per capita health expenditure. An increase in health expenditure requires a high level of education [22]. Similarly, a higher level of education is assumed to increase the disposable income of households and individuals, and potentially reduce income inequality [13]. A negative sign is expected.

High inflation is associated with high income inequality because there is a differential protection of income flows against inflation [10]. For example, low-income wage earners are generally much less protected from cyclical fluctuations in real wages, such as the minimum wage [28]. As a result, a positive sign is expected.

The quality of institutions is measured by a composite index of institutional quality constructed from WGI's (Worldwide Governance Indicators) six (06) governance indicators. Good institutional quality further promotes the mobilization of direct tax revenues, which are progressive taxes, and thus improves income distribution [18]. A negative sign is expected.

The research sample covers the eight (08) WAEMU countries from 1996 to 2015 . The choice of the research period is based on the availability of data. The Gini inequality index of household disposable income is derived from the Standardized World Income Inequality Database (SWIID) [41]. Data on different types of tax revenues are taken from the African Development Bank database [1] and data on the quality of institutions are taken from the Worldwide Governance Indicators database [45]. Data on per capita income, inflation rate and health expenditure are taken from World Development Indicators database [44].

\subsection{Estimation Methods}

One of the peculiarities of the data in the SWIID database is that the data imputation process makes it possible to obtain bias-correcting estimators in case of the presence of non- 
stationarity of the variables [40]. Thus, classical unit root tests are no longer necessary when these data are used in a regression. Moreover, the configuration of these data does not even allow these tests to be carried out. This is why, in the literature, works using these data do not perform unit root tests $[2,4,43]$. While it is true that this database is somewhat unique, it has been increasingly used in the analysis of income inequality in recent years. Indeed, it is the only database in the world with a maximum of data available over a long period of time for several countries. This database is a treasure trove for researchers, particularly for those interested in the analysis of inequalities in WAEMU countries because, generally speaking, such data are very little, if any, available for these countries.

This being the case, the choice of the estimation technique best suited to this research is made on the basis of the very data structure of this research.

The data are panel data with an individual dimension that is smaller than the time dimension. In addition, there are endogenous variables: the variables of taxation and institutional quality. High levels of inequality increase incentives to mobilize tax revenues, and conversely, increased tax revenue mobilization reduces income inequality $[2,8]$. Also, a favourable institutional environment facilitates the reduction of income inequality and high-income inequality reduces the possibilities of maintaining the proper functioning of countries' institutional framework [28].

Fixed effects (FE) and ordinary least squares (OLS) models are inefficient in the presence of variable endogeneity. If the desire is to estimate all the parameters of the structural form (FS) and all the equations simultaneously, the triple least squares (3SLS) method, which is referred to as a "full information" technique, was the most appropriate. However, in this research, there are only isolated equations of the system, so this method cannot be used. The generalized method of moments (GMM) is particularly recommended when the time dimension is small compared to the individual dimension. Since the time dimension is larger than the individual dimension, the GMM is not relevant either. Finally, the double least squares (2SLS) are retained because they better correspond to the data structure.

Indeed, the 2SLS make it possible to solve the problems of endogeneity. In practice, this method allows a regression to be carried out by substituting the variable which potentially suffers from endogeneity with an instrumental variable. We take the lagged value of each endogenous variable as the instrumental variable. The following three hypotheses support the choice of instrumental variables: First, the error term must not be correlated with the instrumental variable. Second, the variable assumed to be endogenous must be highly correlated with the instrumental variable. Finally, the instrumental variable must be different from the variable which suffers from endogeneity, even by a multiple. If the first condition is difficult to verify, it is possible to verify the second and last condition through the correlation matrix (see table 3 in appendices) and descriptive statistics (see table 2 in appendices), respectively.
Indeed, table 2 in appendices indicates a difference between each endogenous variable and its instrument. As for table 3 in appendices, it shows a strong correlation, significant at $5 \%$, between each endogenous variable and its instrument.

It should be noted that some authors have also used the lagged value of an endogenous variable as an instrumental variable $[12,25]$.

\section{Results and Discussions}

Table 1 summarizes the results of estimates of the effect of tax revenue mobilization on income inequality in WAEMU countries using the 2SLS. Before the economic analysis of the results, it is necessary to verify the adequacy of the model.

We question the overall significance of the model, i.e., whether all the explanatory variables have an influence on the dependent variable. This test can be formulated as follows: is there at least one significant explanatory variable?

The assessment of the overall quality of the model is made with the Fischer statistic, which indicates whether the explanatory variables have an influence on the dependent variable. Let the following assumptions be made: H0: all the coefficients of the model are zero; H1: there is at least one non-zero coefficient. The trade-off is made by comparing the probability associated with the F-statistic with the 5\% threshold retained. If the probability associated with Fstatistics calculated is less than $5 \%$, then the hypothesis $\mathrm{H} 0$ will be rejected in favour of the alternative hypothesis that the regression is globally significant.

In our case, the probability associated with the Fischer statistic is less than $5 \%$ in each equation (I to V). The model is therefore globally significant and of good quality.

We will now check whether the explanatory variables used in our model have the expected signs and highlight their importance in the evolution of income inequality.

Equation (I) presents the effect of the total tax burden on income inequality. The coefficient associated with this variable is negative and significant. This means that in WAEMU countries, an increase in the level of total tax revenue leads to a reduction in income inequality: an increase of one percentage point in the total tax burden leads to a reduction in income inequality of 0.00408 points. Dao and Godbout find similar results for OECD countries from 1970 to 2010. Indeed, an improvement in total tax revenues can translate into higher pro-poor public spending, ceteris paribus [12]. According these authors, this requires that the poor are not the net contributors to the system and that they, along with the vulnerable, should be the primary beneficiaries of such public spending. For example, in recent years in Niger, broadening the tax base in sectors other than agriculture has led to a reduction in poverty and income inequality. The low level of the coefficient can be explained by low tax revenues in these countries. It is in this sense that Chu, Davoodi, and Gupta point out that the low capacity to mobilize total tax revenues in developing countries limits the use of taxation as an instrument of income redistribution [11]. In fact, as 
mentioned in previous essays, over the period 1996-2015, the average tax burden of these countries is not only lower than that of African countries, but also, and more importantly, at the minimum suggested in the multilateral surveillance of WAEMU countries. In any case, the results show that over the period 1996-2015, the mobilization of total tax revenues in the WAEMU zone favours an equal distribution of income.

Equation (II) shows the effect of direct taxation on income inequality. It shows that the coefficient of the variable is negative and significant. It follows that an increase in direct taxes of one percentage point leads to a reduction in income inequality of 0.01773 points. These results reinforce those of other authors [20, 28]. In fact, progressive income taxation allows for an effective redistribution of income from richer to poorer populations, which contributes strongly to the reduction of income inequality. Although the coefficient of the direct tax burden variable is higher than that of the total tax burden, it is just as low as the latter. To this end, Bird and Zolt point out that the progressive effect of direct taxation is weak in developing countries because, generally speaking, in these countries, personal income tax is neither exhaustive nor very progressive and the administrative costs of these types of taxes are very high [7]. This is not to say that these authors are preaching the abolition or reduction of personal income tax. On the contrary, they draw the attention of developing countries to the need for much greater efforts in mobilizing this type of tax revenue in order to improve their redistributive effects. For the specific case of WAEMU countries, over the period 1996-2015, the rate of direct tax pressure on average increased from $2.93 \%$ to $4.09 \%$, i.e., an increase of about $39.59 \%$ [1]. At the country level, it can be seen that over the period 1996-2015, direct tax revenue is higher than indirect domestic tax revenue in Côte d'Ivoire, Mali and Togo. According to the 2018 annual report on the functioning and development of the Union, the fiscal performance of direct revenue can be explained by measures to broaden the tax base and strengthen controls (in particular, the interconnection of tax authorities and the fight against fraud). In any case, it appears that the collection of direct tax revenue improves the distribution of income in WAEMU countries.

Table 1. Effect of tax revenues on income inequality after redistribution in WAEMU countries by the 2SLS.

\begin{tabular}{|c|c|c|c|c|}
\hline Inégalités après redistributions & (I) & (II) & (III) & (IV) \\
\hline Total fiscal pressure & $-0.00408 *(0.086)$ & & & \\
\hline Direct tax pressure & & $-0.01773 * * *(0.019)$ & & \\
\hline Indirect domestic tax pressure & & & $-0.00119(0.749)$ & \\
\hline GDP per capita & $0.18797 * * *(0.000)$ & $0.18626 * * *(0.000)$ & $0.16672 * * *(0.003)$ & $0.16349 * * *(0.000)$ \\
\hline Education & $-0.0055^{* * *}(0.001)$ & $-0.00532 * * *(0.001)$ & $-0.0053 * * *(0.003)$ & $-0.0054 * * *(0.001)$ \\
\hline Inflation & $-0.00121(0.263)$ & $-0.00117(0.256)$ & $-0.00129(0.249)$ & $-0.00131(0.244)$ \\
\hline F test & $1105.19 * * *(0.0000)$ & $1165.70 * * *(0.0000)$ & $1074.97 * * *(0.0000)$ & $1101.06 * * *(0.0000)$ \\
\hline Average RVI & 1.7104 & 1.9005 & 1.5819 & 1.5118 \\
\hline Largest FMI & 0.7108 & 0.7404 & 0.6417 & 0.6966 \\
\hline Number of observations & 100 & 100 & 100 & 100 \\
\hline
\end{tabular}

Note: The values in brackets are the p-values: $* * *$ significant at $1 \%, * *$ significant at $5 \%$ and $*$ significant at $1 \%$.

Equations (III) and (IV) give the effects of indirect tax revenues (domestic and commercial) on income inequality. It appears that the redistributive effect of these types of taxes is insignificant in WAEMU countries. In other words, the mobilization of indirect domestic tax revenues and commercial tax revenues are neutral in the distribution of income within the WAEMU zone. Under these conditions, it is accepted that tax policy in these countries has been able to maintain the neutral character of these types of tax revenue. These results confirm those of Devarajan and Hossain whose analysis focuses on the Philippines [14]. Thus, within WAEMU countries, indirect taxation cannot be used as an instrument of income redistribution. In fact, since the 1990s, WAEMU countries, in order to compensate for tax losses resulting from the reduction of customs tariffs, have adopted a reform of domestic taxation focused mainly on the development of VAT. However, VAT is a proportional tax par excellence, as it is governed by liberal principles of fiscal neutrality: taxation must not disrupt individual choices in the allocation of resources. In practice, the customs union is effective in the area, with the abolition of customs duties on trade in originating products between Member States and the establishment of a Common External Tariff (CET). These tax reforms thus explain the neutrality of the effects of indirect taxation in the WAEMU zone.

With regard to the control variables, per capita income and education have a significant effect on income inequalities. The coefficients of these variables show the expected signs.

To summarize, the results show that, in WAEMU countries, the mobilization of direct tax revenue improves income distribution while indirect taxation is neutral.

\section{Conclusion and Recommendation}

The objective of this paper is to analyses the effect of tax revenue mobilization on income inequality in WAEMU countries over the period 1996 to 2015 . In practical terms, the effect of different types of tax revenue (total tax pressure, direct tax pressure, indirect domestic tax pressure and commercial tax pressure) on income inequality is analyzed. The 2SLS are used as an estimation technique.

In line with the hypothesis of the paper, the results show 
that an increase in the level of total tax revenues as well as in direct tax revenues leads to a significant reduction in income inequality. On the other hand, indirect domestic tax revenues and trade tax revenues are neutral. The results also reveal that low growth rates increase income inequality while an improvement in education levels reduces income inequality.

Economic policy recommendations may emerge from these results. First, the broadening of tax bases should be continued and intensified to improve the mobilization of direct and total tax revenues. An improvement in tax revenue leads to increased public expenditure (benefiting the poorest) and consequently to a reduction in income inequality, ceteris paribus. Second, increase the progressivity of direct taxation (personal income and profit tax). Finally, strategies must be developed to improve per capita income and education levels in order to curb their distorting effects on income distribution For example, States can develop programs to improve educational attainment and vocational training especially for the most disadvantaged. This will make it possible to break the vicious circle of the transmission of income inequalities from one generation to the next. Finally, this article suggests a comparative analysis of the effect of public expenditure and its components on income inequalities. This will provide an overview of the effect of fiscal policies on income inequality in order to plan effective and efficient budgetary adjustments for better income redistribution in the WAEMU zone.

\section{Appendix}

Table 2. Descriptive statistics of the redistributive effects of the tax burden.

\begin{tabular}{llllll}
\hline Variable & Observations & Moyennes & Ecart-type & Minimum & Maximum \\
\hline Gini & 128 & 40.68672 & 2.3773 & 35.1 & 45.9 \\
educ & 104 & 8.243593 & 3.782329 & 2.234364 & 18.65624 \\
inf & 128 & 4.408752 & 8.704307 & -7.594284 & 80.89967 \\
tpf & 123 & 14.95911 & 3.449963 & 7.578451 & 23.1909 \\
tpfd & 123 & 3.245765 & 1.030459 & 0.803091 & 5.295998 \\
tpfi & 123 & 4.048942 & 2.417807 & 1.42636 & 10.33402 \\
tpfc & 123 & 5.013645 & 2.187719 & 1.328237 & 11.94275 \\
wgi & 128 & 0.0338705 & 0.969402 & -1.91778 & 2.255733 \\
ltpf & 115 & 14.79082 & 3.384671 & 7.578451 & 22.20033 \\
ltpfd & 115 & 3.187875 & 1.027812 & 0.803091 & 5.235998 \\
ltpfi & 115 & 3.982003 & 2.383397 & 1.42636 & 10.33402 \\
ltpfc & 115 & 5.001745 & 2.112845 & 1.328237 & 10.89238 \\
lwgi & 120 & 0.0304606 & 0.9903093 & -1.91778 & 2.255733 \\
\hline
\end{tabular}

Note: tpf, tpfd, tpfi and tpfc represents respectively the rate of total fiscal revenue, the rate of direct fiscal revenue, the rate of domestic indirect fiscal revenue and the rate of trade fiscal revenue. ltpf, ltpfd, ltpfi and ltpfc represents the lagged values of these respective variables.

Table 3. The correlation matrix of the redistributive effects of the tax burden.

\begin{tabular}{|c|c|c|c|c|c|c|c|c|c|c|c|}
\hline & Gini & tpf & tpfd & tpfi & tpfc & wgi & Itpf & Itpfd & Itpfi & Itpfc & lwgi \\
\hline Gini & 1.0000 & & & & & & & & & & \\
\hline tpf & 0.0470 & 1.0000 & & & & & & & & & \\
\hline tpfd & -0.0034 & $0.8491 *$ & 1.0000 & & & & & & & & \\
\hline tpfi & -0.0726 & $0.4990 *$ & $0.4803 *$ & 1.0000 & & & & & & & \\
\hline tpfc & $0.2561 *$ & $0.4543 *$ & $0.2265^{*}$ & $-0.356^{*}$ & 1.0000 & & & & & & \\
\hline wgi & -0.0073 & $0.2263 *$ & $0.2106^{*}$ & $0.5530 *$ & $-0.218^{*}$ & 1.0000 & & & & & \\
\hline ltpfd & 0.0294 & $0.8283^{*}$ & $0.9191 *$ & $0.4622 *$ & $0.2387 *$ & $0.1958 *$ & $0.8579 *$ & 1.0000 & & & \\
\hline ltpfi & -0.0721 & $0.4816^{*}$ & $0.4875^{*}$ & $0.9521 *$ & $-0.354^{*}$ & $0.5449^{*}$ & $0.4962 *$ & $0.4711^{*}$ & 1.0000 & & \\
\hline ltpfc & $0.2596^{*}$ & $0.4297^{*}$ & $0.1962 *$ & $-0.334^{*}$ & $0.9353^{*}$ & $-0.187 *$ & $0.4394 *$ & $0.2469 *$ & $-0.370^{*}$ & 1.0000 & \\
\hline lwgi & -0.0243 & $0.2129 *$ & $0.2129 *$ & $0.5760 *$ & $-0.247^{*}$ & $0.9551 *$ & $0.2404^{*}$ & $0.2173^{*}$ & $0.558 *$ & $-0.206^{*}$ & 1.00 \\
\hline
\end{tabular}

Note: tpf, tpfd, tpfi and tpfc represents respectively the rate of total fiscal revenue, the rate of direct fiscal revenue, the rate of domestic indirect fiscal revenue and the rate of trade fiscal revenue. 1 tpf, ltpfd, ltpfi and ltpfc represents the lagged values of these respective variables.

[3] Alesina, A., \& Rodrik, D. (1994). Distributive politics and economic growth. Quarterly Journal of Economics 109, no. 2, 465-490.

\section{References}

[1] African Development Bank database (ADB, 2018).

[4] Ball, L., Furceri, D., Leigh, D., \& Loungani, P. (2013). The distributional effects of fiscal consolidation. IMF Working Paper $/ 13 / 151$.

[2] Agnello, L., \& Sousa, R. M. (2014). How does fiscal consolidation impact on income inequality ?. Review of Income and Wealth Series 60, Number 4, 702-726.

[5] Barro, Robert J. (2000). Inequality and Growth in a Panel of Countries. Journal of Economic Growth, 5: 5-32. 
[6] Bird, R. M., \& De Wulf, L. H. (1973). Taxation and Income Distribution in Latin America: A Critical Review of Empirical Studies. Staff Papers (International Monetary Fund), Vol. 20, No. 3, 639-682.

[7] Bird, R. M., \& Zolt, E. M. (2005). The limited role of the personal income tax in developing countries. Journal of Asian Economics 16, 928-946.

[8] Bird, R. M., Martinez-Vazquez, J., \& Torgler, B. (2004). Societal Institutions and Tax Effort in Developing Countries. International Studies Program, Working Paper 04-06.

[9] Bobe, B. (1975). Budget de l'Etat et redistribution des revenus. Revue économique, volume $26, n^{\circ} 1,1-35$.

[10] Bulir, A. (2001). Income Inequality: Does inflation matter? IMF Staff Papers 48 (1), 139-159.

[11] Chu, K.-y., Davoodi, H., \& Gupta, S. (2000). Income distribution and tax and government social spending policies in developing countries. IMF Working Paper.

[12] Dao, H., \& Godbout, L. (2014). Le rôle de la fiscalité dans la réduction des inégalités: doit-on se soucier de la structure fiscale servant à prélever les recettes? L'Actualité économique, Revue d'analyse économique, vol. 90, no 4, décembre, 303328.

[13] De Gregorio, J., \& Lee, J. (2002). Education and income inequality: New evidence from cross-country Data. Review of Income and Wealth, 48 (3), 395-416.

[14] Devarajan, S., \& Hossain, S. (1998). The combined incidence of taxes and public expenditures in the Philippines. World Development Vol. 26, No. 6, 963-977.

[15] De Wulf, L. (1975). Fiscal incidence studies in developing countries: survey and critique. Staff Papers (International Monetary Fund), Vol. 22, No. 1, 61-131.

[16] De Wulf, L. (1977). Budget de l'Etat et redistribution des revenus: quelques aspects théoriques. Revue économique volume $28, n^{\circ} 2,209-220$.

[17] Dischamps, J.-C. (1960). Comportements économiques et distorsions fiscales. Paris: Presses universitaires de France.

[18] Duncan, D., \& Peter, K. S. (2008). Tax progressivity and income inequality. Andrew Young School of Policy Studies, Research Paper Series.

[19] Gautier, J.-F. (2001). Taxation optimale et réformes fiscales: Une revue de littérature tropicalisée. DIAL (Developpement et insertion international).

[20] Gemmell, N., \& Morrissey, O. (2005). Distribution and poverty impacts of tax structure reform in developing countries: How little we know. Development Policy Review, 131-144.

[21] Goni, E., Lopez, H., \& Serven, L. (2011). Fiscal redistribution and income inequality in Latin America. World Development Vol. 39, No. 9, 1558-1569.

[22] Grossman, M. (1972). On the concept of health capital and the demand for health. The Journal of Political Economy, 80 (2), 223-255.

[23] Harberger, A. C. (1962). The incidence of the corporation income tax. The Journal of Political Economy, Vol. 70, No. 3, 215-240.
[24] Kim, N. N., \& Kim, J. (2013). Income Inequality in Korea, 1933-2010: Evidence from Income Tax Statistics. Working Paper 2013-05.

[25] Kpodar, Kangni. (2007). Manuel d'initiation à stata (version 8) Centre d'Etudes et de Recherches sur le Developpement International (CERDI), Clermont-Ferrand.

[26] Kuznets, S. (1955). Economic Growth and Income Inequality. The American Economic Review, Vol. 45, No. 1, 1-28.

[27] Kuznets, S. (1963). Quantitative Aspects of the Economic Growth of Nations: VIII. Distribution of Income by Size. Economic Development and Cultural Change, Vol. 11, No. 2, Part 2, 1-80.

[28] Martinez-Vazquez, J., Vulovic, V., \& Dodson, B. M. (2012). The impact of tax and expenditure policies on income disttribution: Evidence from a large panel of countries. Hacienda Pública Española 200.

[29] Mieszkowski, P. (1969). Association tax incidence theory: The effects of taxes on the distribution of income. Journal of Economic Literature, Vol. 7, No. 4, 1103-1124.

[30] Mirrlees, J. A. (1971). An exploration in the theory of optimum income taxation. The Review of Economic Studies, Vol. 38, No. 2, 175-208.

[31] Moyes, P., \& Trannoy, A. (1999). Le quotient familial: une structure fiscale cohérente avec le critère de Lorenz relatif. Économie \& prévision, $n^{\circ} 138-139,1999-2-3$. Economie des inégalités, 111-124.

[32] Mulas-Granados, C. (2005). Fiscal ddjustments and the shortterm trade-off between economic growth and equality. Hacienda Pública Española / Revista de Economía Pública, $172,61-92$.

[33] Mwega, R. M. (1986). Incidence of taxes and transfers in Kenya: A general equilibrium analysis. Eastern African Economic Review, Vol 2 (June), 6-13.

[34] Paulus, A., Čok, M., Figari, F., Hegedüs, P., Kump, N., Lelkes, O.,... Vorrk, A. (2009). The effects of taxes and benefits on income distribution in the enlarged EU. EUROMOD Working Paper, No. EM8/09, University of Essex, Institute for Social and Economic Research (ISER), Colchester.

[35] Peter, K. S., Buttrick, S., \& Duncan, D. (2009). Global Reform of Personal Income Taxation, 1981-2005: Evidence from 189 Countries. IZA Discussion Paper No. 4228.

[36] Piketty, T. (2013). Le capital au xxie siècle. Paris: Editions du Seuil.

[37] Piketty, t., \& Saez, E. (2003). Income inequality in the united states, 1913-1998*. The quarterly journal of economics vol. cxviii february issue 1 .

[38] Ramsey, F. (1927). A contribution to the theory of taxation. The economic journal, volume 37, Issue 145, 47-61.

[39] Sahn, D., \& Younger, S. (1998). Poverty and Fiscal Policy: Microeconomic Evidence. Mimeograph; Cornell University.

[40] Solt, F. (2019). Measuring Income Inequality Across Countries and Over Time: The Standardized World Income Inequality Database. SWIID Version 8.1, May 2019.

[41] Standardized World Income Inequality Database (SWIID). (2019). 
[42] Westlake, M. (1973). Tax Evasion, tax Incidence and the Distribution of Income in Kenya. Eastern Africa Economic Review, Vol. 5, no. 1, 1-27.

[43] Woo, J., Bova, E., Kinda, T., \& Zhang, Y. S. (2013). Distributional consequences of fiscal consolidation and the role of Fiscal Policy: What do the data say? IMF Working Paper.

[44] World Development Indicators database (2018).

[45] Worldwide Governance Indicators database (2018).
[46] Younger, S. D. (1993). Estimating Tax Incidence in Ghana: An Exercise Using Household Data. Cornell Food and Nutrition Policy Program Working Paper No. 48.

[47] Younger, S. D., Sahn, D. E., Haggblade, S., \& Dorosh, P. A. (1999). Tax incidence in Madagascar: An analysis using household data. The World Bank Economic Review, Vol. 13, No. 2, 303-331. 